\title{
Pengembangan LKPD Simulasi Wave on String untuk Pembelajaran Gelombang Stasioner di SMA
}

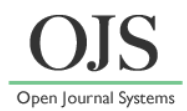

\author{
Rahman Eka Cahya*, Imam Sucahyo \\ Jurusan Fisika, Fakultas Matematika dan Ilmu Pengetahuan Alam, Universitas Negeri Surabaya \\ Jl. Ketintang, Surabaya 60231, Indonesia \\ "Email: rahman.17030184035@mhs.unesa.ac.id
}

DOI: https://doi.org/10.33369/pendipa.5.3.366-371

\begin{abstract}
[The Development of Wave on String Simulation as Students Worksheet for High School Students on Stastionary Wave Learning] This research aims to describe the feasibility of Wave on String learning media and the feasibility of student's worksheets, as well as students' responses on stationary wave material, especially wave on string material in the form of effectiveness of the application and feasibility of the developed media. The method applied to this research was the developmental research method of RnD (Research and Development). The applied method was purposed to developing and producing applicable learning media according to validators' assessments. The application of learning media is intended for 25 students at $2^{\text {nd }}$ degree high school of SMA Hang Tuah 2 Sidoarjo by applying Wave on String media and students' worksheets, as well as giving pre-test, post-test, and questionnaire. The results of the research indicated media validity rate of $94.18 \%$ and classified as very valid, the effectiveness of pre-test-post-test by $80.03 \%$ which is considered effective to improve learning outcomes, students' responses to Media Wave on String and students' worksheets by $86.67 \%$ and $84.00 \%$ which is classified as very practical, as well as the practical results of students relevant to the existing theories, so that the Media Wave on String and the students' worksheets are eligible to be applied in the study of stationary wave on string materials for $2^{\text {nd }}$ grade high school students.
\end{abstract}

Keywords: Student's worksheets, Wave on String, learning media, stationary wave, effectivity.

\begin{abstract}
ABSTRAK
Penelitian ini bertujuan untuk mendeskripsikan kelayakan media pembelajaran Wave on String dan kelayakan Lembar Kerja Peserta Didik (LKPD), serta respon peserta didik terhadap materi gelombang stasioner, khususnya gelombang pada tali yang berupa efektivitas penerapan dan kelayakan media pembelajaran yang dikembangkan. Metode yang digunakan pada penelitian ini adalah metode penelitian pengembangan dengan model $\mathrm{RnD}$ (Research and Development). Metode penelitian yang diterapkan hanya sebatas pada mengembangkan dan menghasilkan media pembelajaran yang valid untuk diaplikasikan berdasarkan penilaian para validator. Pengaplikasian media pembelajaran ditujukan kepada 25 (dua puluh lima) peserta didik kelas XI di SMA Hang Tuah 2 Sidoarjo dengan mengaplikasikan Media Wave on String dan LKPD, serta memberikan pre-test, post-test, dan angket respon. Hasil penelitian yang diperoleh mengindikasikan tingkat kevalidan media yang dikembangkan sebesar $94.18 \%$ yang tergolong sangat valid, efektivitas pemberian pre-test-post-test kepada peserta didik sebesar $80.03 \%$ yang tergolong efektif untuk meningkatkan hasil belajar, respon peserta didik terhadap efektivitas pengaplikasian Media Wave on String sebesar $86.67 \%$, respon peserta didik terhadap efektivitas pengaplikasian LKPD sebesar $84.00 \%$ yang tergolong sangat praktis, serta hasil praktikum peserta didik menunjukkan hasil yang sangat relevan dengan teori-teori gelombang stasioner yang ada, sehingga Media Wave on String dan LKPD yang dikembangkan layak untuk diaplikasikan sebagai media pembelajaran gelombang stasioner, khususnya materi gelombang pada tali untuk peserta didik kelas XI SMA.
\end{abstract}

Kata kunci: LKPD, Wave on String, media pembelajaran, gelombang stasioner, efektivitas. 


\section{PENDAHULUAN}

Pembelajaran di sekolah pada jenjang SMA telah mengalami perkembangan sesuai dengan Kurikulum 2013 Revisi Terbaru, serta mengalami penyesuaian metode pembelajaran selama masa pandemi Covid-19 dengan menerapkan sistem pembelajaran jarak jauh atau daring. Oleh karena itu, melalui perkembangan dan penyesuaian tersebut, peserta didik ditekankan untuk mampu belajar dari berbagai sumber informasi, tanpa harus berasal dari guru (Rahayu, 2017). Metode pembelajaran seperti ini dapat digunakan sebagai pengganti metode pembelajaran konvensional yang hanya memfokuskan peserta didik pada pencapaian kemampuan konseptual, namun mengubah metode pembelajaran dari konvensional menjadi daring tentu saja bukanlah perkara mudah (Atsani, 2020). Selama melakukan pembelajaran secara daring tentunya diperlukan dukungan untuk mengintegrasikan semua proses pembelajaran mulai dari kurikulum, materi, proses, dan evaluasi, sehingga dibutuhkan suatu media pembelajaran yang tepat dalam proses manajemen pembelajaran di sekolah (Giatman, 2020).

Berdasarkan hasil wawancara yang dilakukan dengan salah satu guru mata pelajaran fisika di SMA Hang Tuah 2 Sidoarjo yang menyatakan bahwa di SMA Hang Tuah 2 Sidoarjo terdapat laboratorium fisika yang berisikan alat-alat praktikum untuk menunjang penyampaian konsep fisika yang abstrak, namun selama pembelajaran daring alat-alat tersebut tidak kompatibel untuk digunakan, sehingga proses evaluasi tidak dapat dilakukan untuk memenuhi kompetensi dasar keterampilan pada Kurikulum 2013 Revisi Terbaru. SMA Hang Tuah 2 Sidoarjo menerapkan Kurikulum 2013 Revisi Terbaru dengan metode pembelajaran daring selama masa pandemi Covid-19, namun diperlukan suatu terobosan baru terkait alat-alat praktikum atau media pembelajaran yang lebih kompatibel, efektif, dan variatif untuk menyampaikan materi fisika yang abstrak.

Salah satu konsep abstrak dalam fisika yang dapat dijelaskan melalui media/alat peraga pembelajaran adalah gelombang stasioner yang merambat pada tali. Melalui demonstrasi perambatan gelombang pada tali, maka dapat diungkapkan secara alamiah bentuk gelombang itu sendiri, sehingga fenomena gelombang dapat diamati secara visual dan konseptual. Oleh karena itu, visualisasi gelombang yang merambat pada tali penting diterapkan pada media pembelajaran, khususnya materi gelombang stasioner pada jenjang SMA guna memperjelas penyampaian konsep abstrak gelombang stasioner.

Langkah alternatif yang akan coba peneliti lakukan untuk mempermudah peserta didik memahami materi gelombang stasioner adalah mengembangkan sebuah media pembelajaran fisika berupa alat peraga gelombang stasioner dan lembar kerja peserta didik. Penelitian serupa yang relevan telah dilakukan oleh Fatakh Laksono Prabowo dan Imam Sucahyo (2018) menunjukkan, bahwa media pembelajaran gelombang stasioner yang dikembangkan sangat valid dan dapat diaplikasikan sebagai media pembelajaran pada materi gelombang stasioner dengan tingkat kevalidan $85.79 \%$.

Perbedaan penelitian yang akan peneliti lakukan dari penelitian sebelumnya adalah pengembangan alat peraga pembelajaran fisika sekaligus lembar kerja peserta didik yang berupa percobaan gelombang stasioner pada tali menggunakan aplikasi PhET Colorado-Wave on String (versi html terbaru) dan menggunakan aplikasi Adobe Acrobat DC 2019 sebagai pengganti kertas (paperless) untuk pembelajaran non-tatap-muka secara langsung (daring). Berdasarkan pemaparan tersebut, maka peneliti mengajukan judul penelitian, "Pengembangan LKPD Simulasi Wave on String untuk Pembelajaran Gelombang Stasioner di SMA”.

\section{METODE PENELITIAN}

Penelitian yang dilakukan merupakan jenis penelitian pengembangan atau dikenal dengan $\mathrm{RnD}$ (Research and Development) dengan fokus utama berupa pengembangan media pembelajaran fisika berbasis praktikum virtual yang kompatibel digunakan pada sistem pembelajaran daring. Model penelitian yang digunakan adalah penelitian $\mathrm{RnD}$ (Research and Development) yang ditujukan untuk menghasilkan produk yang spesifik, serta menguji efektivitas produk tersebut (Astuti, 2017). Penelitian ini ditujukan kepada 25 sampel peserta didik kelas XI-IPA di SMA Hang Tuah 2 Sidoarjo pada semester genap tahun ajaran 
2020/2021 dengan menggunakan metode onegroup-pre-tes-post-test-design.

Pengumpulan data penelitian dilakukan melalui beberapa metode, yaitu validasi, tes, dan angket respon. Metode validasi ditujukan untuk mengukur tingkat kevalidan media pembelajaran yang dikembangkan, metode tes berupa pre-test dan post-test ditujukan untuk mengukur efektivitas media pembelajaran dan lembar kerja peserta didik yang dikembangkan, serta metode angket respon ditujukan untuk mengukur respon peserta didik terhadap media pembelajaran yang dikembangkan.

\section{HASIL DAN PEMBAHASAN}

Data-data hasil penelitian yang diperoleh berdasarkan metode validasi, tes, dan angket respon yang digunakan berupa hasil validasi perangkat penelitian, hasil uji pre-test, hasil uji post-test, hasil percobaan gelombang pada tali menggunakan aplikasi PhET Colorado-Wave on String (versi html terbaru), serta hasil respon peserta didik.

Validasi perangkat penelitian didasarkan pada penilaian/validasi dua validator ahli, yaitu validator ahli pada bidang pendidikan dan pengajaran di sekolah dan validator ahli pada bidang pengembangan media pembelajaran yang terdapat pada Tabel 1 .

Tabel 1. Hasil Validasi Media Wave on String dan LKPD

\begin{tabular}{|c|c|c|c|c|c|}
\hline \multirow[b]{2}{*}{ No. } & \multirow[b]{2}{*}{ Aspek } & \multicolumn{2}{|c|}{ Validator 1} & \multicolumn{2}{|c|}{ Validator 2} \\
\hline & & 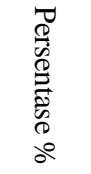 & 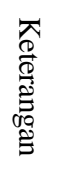 & 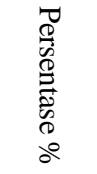 & 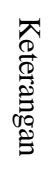 \\
\hline 1. & Kelayakan isi & $100 \%$ & SV & $100 \%$ & SV \\
\hline 2. & Penyajian materi & $87.5 \%$ & SV & $87.5 \%$ & SV \\
\hline 3. & Kebahasaan & $100 \%$ & SV & $91.7 \%$ & SV \\
\hline 4. & Keefektifan & $100 \%$ & SV & $87.5 \%$ & SV \\
\hline 5. & Kesesuaian kurikulum & $93.3 \%$ & SV & $91.7 \%$ & SV \\
\hline 6. & Kebermanfaatan & $100 \%$ & SV & $91.7 \%$ & SV \\
\hline 7. & Nilai pendidikan & $92.9 \%$ & SV & $96.4 \%$ & SV \\
\hline 8. & Keakuratan media & $100 \%$ & SV & $86.7 \%$ & SV \\
\hline
\end{tabular}

Keterangan:

SV : Sangat valid CV : Cukup valid

V : Valid KV : Kurang valid
Berdasarkan pada Tabel 1, penilaian oleh Validator 1 menghasilkan rata-rata validasi sebesar $96.71 \%$, sehingga Media Wave on String dan LKPD berdasarkan skala Likert tergolong kategori sangat valid dan penilaian oleh Validator 2 menghasilkan rata-rata validasi sebesar $91.65 \%$, sehingga Media Wave on String dan LKPD tergolong sangat valid berdasarkan skala Likert.

Pada hasil validasi oleh Validator 2 untuk keakuratan media mendapatkan penilaian paling kecil, yaitu $86.7 \%$. Hal ini dikarenakan keakuratan Media Wave on String dan LKPD memiliki kelemahan pada pengaplikasian substansi materi praktikum di lapangan yang bertujuan mencapai keterampilan peserta didik dalam mengoperasikan alat peraga karena penelitian dilakukan secara daring dan tanpa adanya pendampingan tatap muka secara langsung selama masa pandemi virus Covid-19.

Validator 1 dan Validator 2 memberikan nilai validasi yang berbeda dikarenakan Validator 1 merupakan ahli bidang pendidikan dan pengajaran di sekolah, sedangkan Validator 2 merupakan ahli bidang pengembangan media pembelajaran, khususnya gelombang stasioner.

Nilai Pre-test, Post-test, dan N-Gain peserta didik dapat digambarkan seperti gambar berikut:

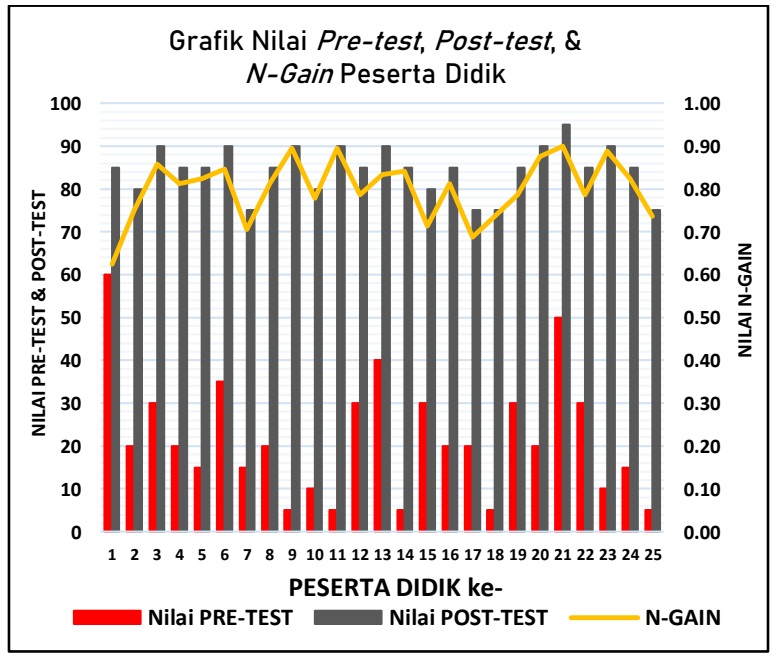

Gambar 1. Hasil Pre-test, Post-test, dan N-Gain Gambar 1 merepresentasikan nilai Pre-test, Posttest, dan $N$-Gain sampel penelitian (peserta didik) dengan rata-rata kenaikan nilai $N$-Gain sebesar 0.80, sehingga perbedaan nilai Pre-test dan Post-test sampel penelitian (peserta didik) tergolong tinggi (adaptasi dari: Hidayat, 2019). 
Nilai Efektivitas $\mathrm{N}$-Gain peserta didik dapat digambarkan seperti gambar berikut:

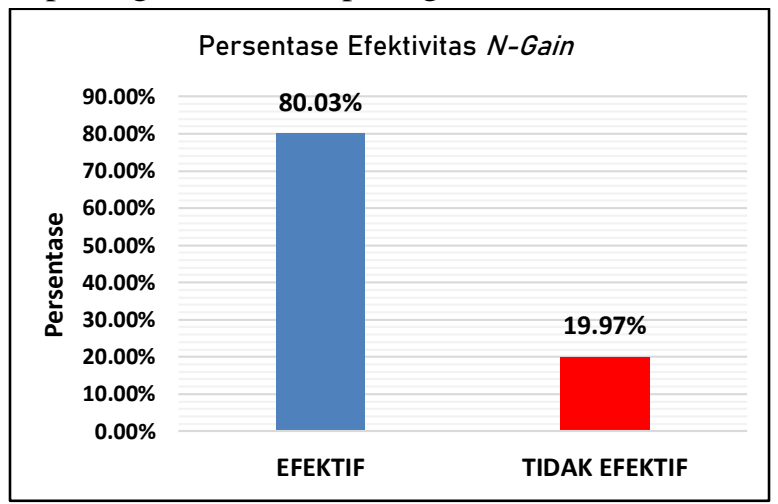

Gambar 2. Persentase Efektivitas $N$-Gain

Gambar 2 menunjukkan nilai Efektivitas $N$-Gain peserta didik dengan persentase efektif sebesar 80.03\% dan persentase tidak efektif sebesar $19.97 \%$, sehingga persentase efektif lebih besar daripada persentase tidak efektif. Oleh karena itu, nilai Efektivitas $N$-Gain tergolong efektif dan dapat disimpulkan bahwa Media Wave on String dan LKPD efektif meningkatkan hasil pembelajaran peserta didik (adaptasi dari: Hidayat, 2019).

Hasil respon peserta didik terhadap Media Wave on String dan LKPD yang dikembangkan dapat digambarkan seperti gambar berikut:

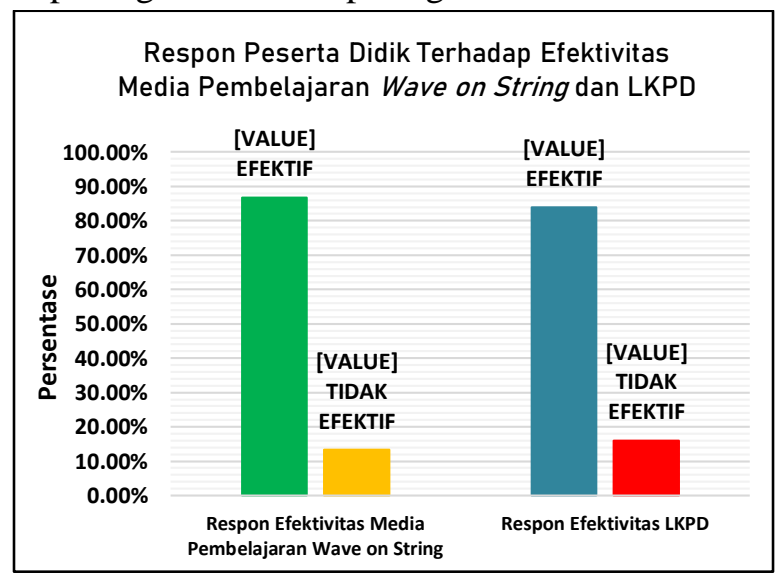

Gambar 3. Hasil Respon Peserta Didik

Gambar 3 merepresentasikan nilai efektivitas hasil angket respon peserta didik terhadap Media Wave on String dan LKPD yang telah dikembangkan. Berdasarkan respon dari 25 responden, bahwa dari kedua grafik didapatkan $86.67 \%$ responden menilai Media Wave on String efektif dan $84.00 \%$ responden menilai LKPD efektif, sehingga rata-rata nilai efektif kedua grafik sebesar $85.34 \%$. Apabila mengacu pada skala Likert, maka efektivitas Media Wave on String dan LKPD yang telah dikembangkan tergolong sangat praktis dan dapat diaplikasikan pada pembelajaran di sekolah, yaitu gelombang stasioner, khususnya materi gelombang pada tali (adaptasi dari: Jannah, 2017).

Untuk hasil praktikum peserta didik menggunakan aplikasi Phet Colorado-Wave on String (versi html terbaru), terdapat dua kali percobaan atau manipulasi, yaitu percobaan pertama dilakukan dengan manipulasi tali ujung bebas dan percobaan kedua dilakukan dengan manipulasi tali ujung terikat, kemudian menulis data yang diperoleh menggunakan aplikasi Adobe Acrobat DC 2019. Pada saat peserta didik melakukan percobaan gelombang pada tali dengan manipulasi ujung bebas, maka diperoleh data percobaan pada Gambar 4 dan Gambar 5.

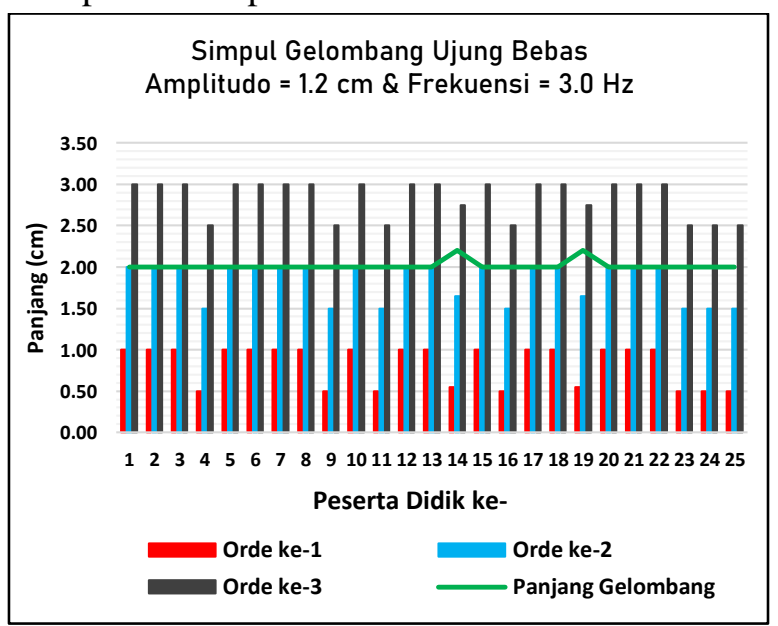

Gambar 4. Hasil Percobaan SIMPUL

Gelombang Stasioner (Tali Ujung Bebas)

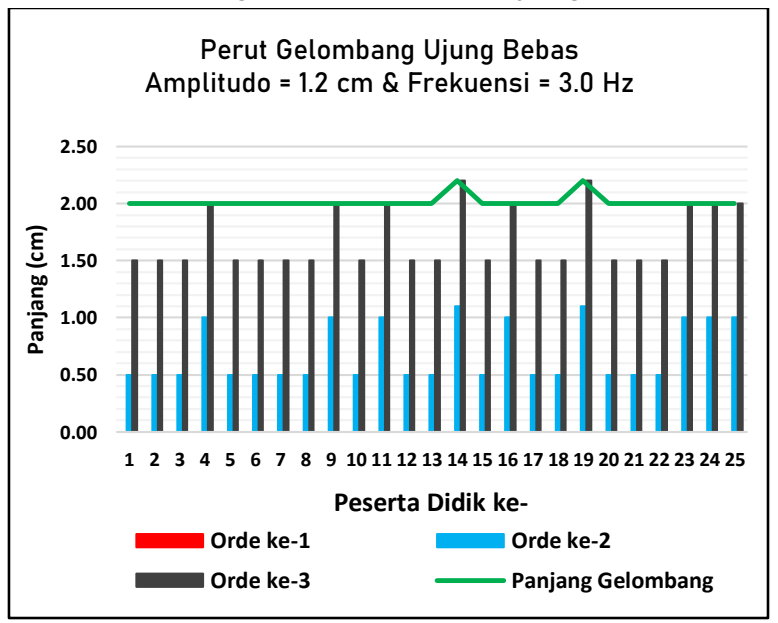

Gambar 5. Hasil Percobaan PERUT Gelombang Stasioner (Tali Ujung Bebas) 
Pada Gambar 4 didapatkan nilai simpul gelombang pada tali ujung bebas yang mana semakin bertambahnya nilai simpul sebanding dengan bertambahnya orde simpul, begitu pula pada Gambar 5 dengan semakin besar orde perut, maka diperoleh nilai perut yang semakin besar, akan tetapi untuk orde perut ke-1 diperoleh nilai 0 (nol) pada setiap percobaan peserta didik. Hal ini dikarenakan amplitudo gelombang mencapai nilai maksimum atau $\cos (k x)=1$, sehingga nilai orde perut gelombang ujung bebas bernilai 0 (nol) pada saat bergetar.

Pada saat peserta didik melakukan percobaan dengan memanipulasi ujung tali pada gelombang menggunakan tali ujung terikat, maka diperoleh data-data hasil percobaan peserta didik yang dapat direpresentasikan pada Gambar 6 dan Gambar 7.

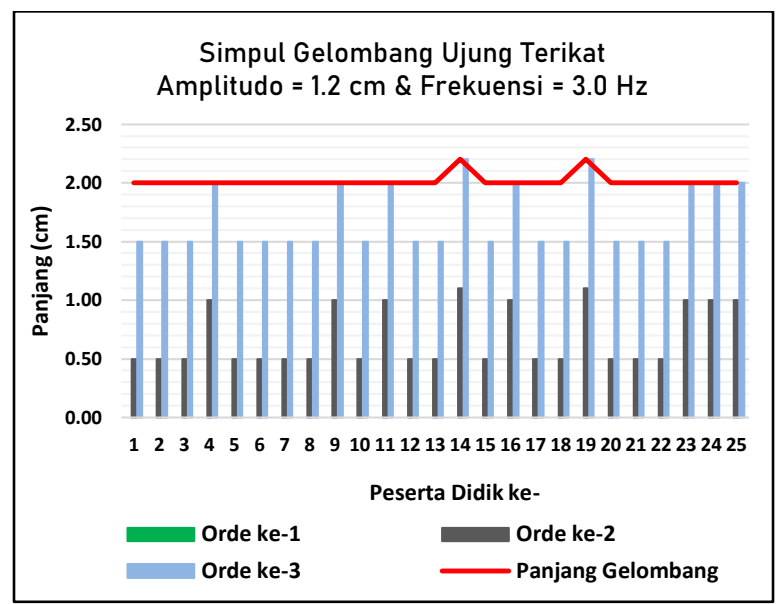

Gambar 6. Hasil Percobaan SIMPUL Gelombang Stasioner (Tali Ujung Terikat)

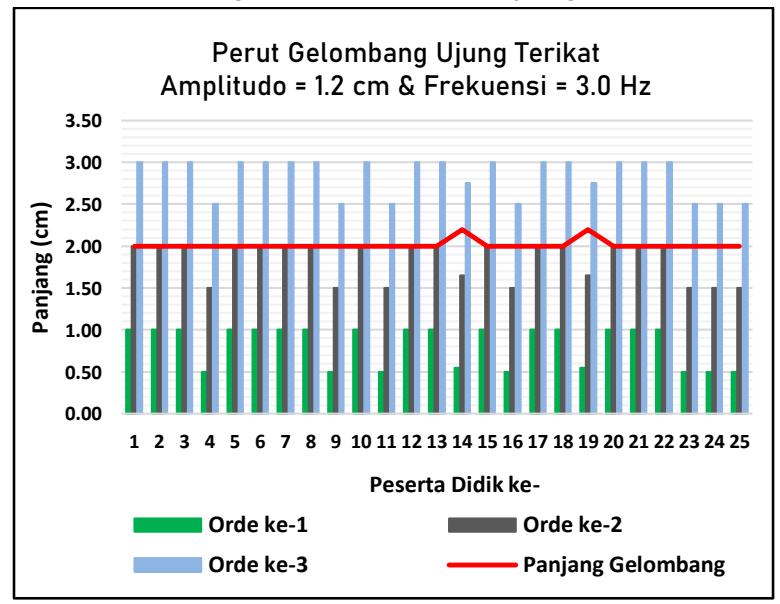

Gambar 7. Hasil Percobaan PERUT Gelombang Stasioner (Tali Ujung Terikat)
Pada Gambar 6 didapatkan nilai simpul gelombang pada tali ujung terikat, bahwa semakin bertambahnya nilai simpul sebanding dengan bertambahnya orde simpul, begitu pula pada Gambar 7 dengan semakin besar orde perut, maka diperoleh nilai perut yang semakin besar, akan tetapi untuk orde simpul ke-1 diperoleh nilai 0 (nol) pada setiap percobaan peserta didik. Hal ini dikarenakan amplitudo gelombang mencapai nilai maksimum atau $\sin (k x)=1$ dan terjadi beda fase sebesar setengah gelombang $\left(180^{\circ}\right)$ atau sebesar $\pi$, sehingga nilai orde simpul gelombang ujung terikat bernilai 0 (nol) pada saat bergetar.

Dengan peserta didik memperoleh nilai simpul dan perut pada setiap orde untuk tali ujung bebas dan tali ujung terikat, maka dapat diperoleh nilai konstanta gelombang stasioner pada masing-masing tali, yaitu pada Gambar 8 dan Gambar 9.

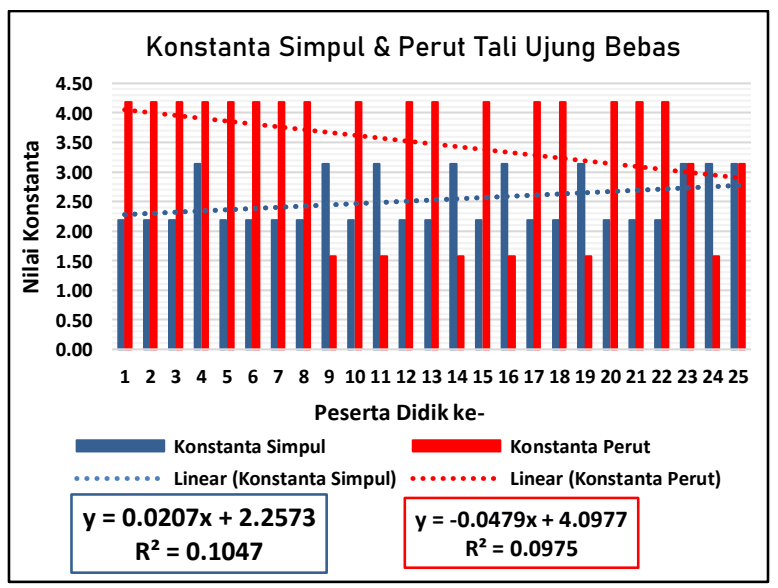

Gambar 8. Hasil Konstanta SIMPUL \& PERUT Gelombang Stasioner (Tali Ujung Bebas)

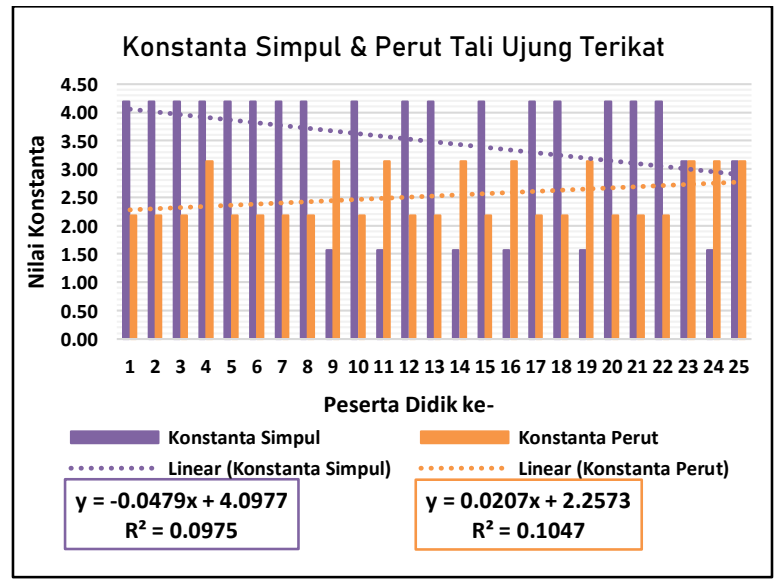

Gambar 9. Hasil Konstanta SIMPUL \& PERUT Gelombang Stasioner (Tali Ujung Terikat) 
Berdasarkan pada percobaan peserta didik untuk gelombang pada tali ujung bebas, maka pada Gambar 8 diperoleh nilai konstanta simpul dan konstanta perut yang hampir sama pada setiap percobaan yang dilakukan peserta didik dengan rata-rata konstanta simpul sebesar 2.53 atau $0.8 \pi$ dan rata-rata konstanta perut sebesar 3.47 atau sebesar $1.1 \pi$.

Pada percobaan yang dilakukan peserta didik untuk gelombang pada tali ujung terikat, maka pada Gambar 9 diperoleh nilai konstanta simpul dan konstanta perut yang hampir sama pada setiap percobaan yang dilakukan peserta didik dengan rata-rata konstanta simpul sebesar 3.47 atau $1.1 \pi$ dan rata-rata konstanta perut sebesar 2.53 atau $0.8 \pi$ yang mana kebalikan dari konstanta simpul dan perut ujung bebas karena terjadi perbedaan fase gelombang sebesar setengah gelombang $\left(180^{\circ}\right)$ atau sebesar $\pi$.

\section{KESIMPULAN}

Berdasarkan hasil penelitian tentang pengembangan Media Wave on String dan LKPD, maka media yang dikembangkan layak untuk diaplikasikan sebagai media pembelajaran untuk peserta didik di sekolah yang dapat ditinjau dari beberapa aspek:

(1) Media Wave on String dan LKPD yang dikembangkan tergolong sangat valid dengan rata-rata kevalidan skala Likert sebesar $94.18 \%$,

(2) terjadi peningkatan hasil nilai pre-testpost-test peserta didik sebesar 0.80 (kategori tinggi) dan diperoleh efektivitas perbedaan nilai pre-test dan nilai post-test dengan nilai sebesar $80.03 \%$, sehingga efektif meningkatkan hasil belajar peserta didik,

(3) hasil respon peserta didik terhadap efektivitas Media Wave on String dan LKPD yang dikembangkan sebesar $86.67 \%$ dan $84.00 \%$ yang tergolong sangat praktis dan dapat diaplikasikan pada pembelajaran di sekolah, yaitu pada materi gelombang stasioner, khususnya gelombang stasioner pada tali, dan

(4) hasil percobaan peserta didik menggunakan Media Wave on String dan LKPD mengindikasikan konsep gelombang stasioner pada tali berupa perbedaan fase gelombang sebesar setengah gelombang $\left(180^{\circ}\right)$ atau sebesar $\pi$ pada tali ujung bebas dan tali ujung terikat untuk setiap orde simpul, orde perut, dan konstanta gelombang, sehingga menimbulkan hubungan yang saling bertolak belakang antar manipulasi ujung tali yang digunakan.

\section{DAFTAR PUSTAKA}

Astuti, I.A.D., Sumarni, R.A., Saraswati, D.L. (2017) Pengembangan media pembelajaran fisika mobile learning berbasis android, Jurnal Penelitian \& Pengembangan Pendidikan Fisika, 3(1), 57-62.

Atsani, L.G.M.Z. (2020) Transformasi media pembelajaran pada masa pandemi covid19, Jurnal Studi Islam, 1(1), 82-93.

Giatman, M., Siswati, S., Basri, I.Y. (2020) Online learning quality control in the pandemic covid-19 era in indonesia, Journal of Nonformal Education, 6(2), 168-175.

Hidayat, N. W., Sucahyo, I. (2019) Penerapan media quipper school untuk meningkatkan hasil belajar fisika siswa pada materi gerak harmonik sederhana, Jurnal Inovasi Pendidikan Fisika, 8(2), 708-711.

Jannah, R. (2017) Pengembangan media pembelajaran fisika berbasis mobile learning dengan menggunakan adobe flash cs 6 siswa kelas xi man 2 padang, Natural Science Journal, 3(2), 429-437.

Prabowo, F. L., Sucahyo, I. (2018) Pengembangan media hukum melde berbasis aplikasi physics toolbox sensor suite pada materi gelombang stasioner, Jurnal Inovasi Pendidikan Fisika, 7(2), 165-170.

Rahayu, S., Erman. (2017) Penerapan pendekatan saintifik dengan media simulasi PhET pada materi gelombang untuk meningkatkan pemahaman konsep siswa smp, Jurnal Pendidikan Sains, 5(3), 253-356. 